\title{
Performance Analysis of the Ventilation System for a Surgical Operating Room in Egypt: A Case Study of Mataria Teaching Hospital in Cairo
}

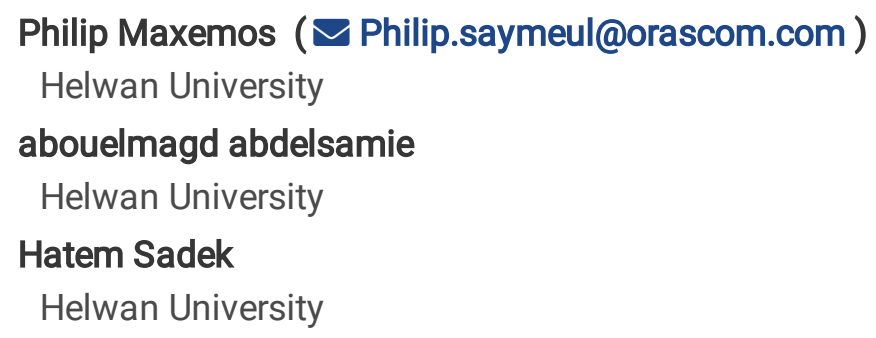

Original Article

Keywords: Ventilation, Air flow distribution, Surgical room Operating room, Indoor air quality, Laminar flow

Posted Date: November 15th, 2021

DOI: https://doi.org/10.21203/rs.3.rs-1030735/v1

License: (c) (i) This work is licensed under a Creative Commons Attribution 4.0 International License. Read Full License 


\section{Abstract}

The Design of the ventilation system in a hospital operating room plays a very important role, not only in providing thermal comfort and hygienic environment for the patients or staff, but also to ensure the scavenging of any contaminants or airborne particles in the operating room theatre that might leak from outside to the operating room or emitting from patients' infections. The present study focuses at airflow distribution, temperature, humidity and velocity profiles in a surgical operating room. An operating room inside the Mataria teaching hospital in Cairo (Egypt) has been chosen for the study. Numerical and experimental studies were carried out, where the room was ventilated through laminar flow diffuser system and $100 \%$ fresh air. The air was released by four outlet grills: two grills at a low level of the floor and two grills at a high level of the floor. In this work, two cases are investigated. In case I, the air outlets have been installed on one side of the room (which already exists in the hospital); and in Case II, the air outlets have been installed on two opposite sides (the suggested case). The results showed that the proposed modification (Case II) performed better distribution of ventilation than Case I. Therefore, it is recommended to install air outlets in two different side areas inside the room in order to avoid the accumulation of contaminants.

\section{Introduction}

A good ventilation design provides a healthy and comfortable environment for people. Poor ventilation, not only makes people feel uncomfortable, but may also lead to infection or an intoxicating environment. Operating Rooms (ORs) are one of the most critical areas that help the controlling of infection. This is where patients are opened to the surrounding environment while in an immune-suppressed condition. The patient is vulnerable to any infectious agents that get into the room and the surgical site. The role of indoor air quality and environmental controls in the improvement of patient and staff health in hospitals is becoming more important these days because of the spread of bacteria and infectious viruses like COVID 19. The factors that affect the occupant's comfort and air

The time of recovery is the time taken by the ventilation system to minimize the airborne particles to a certain level (for more details the reader can review the ISO 14644-1 [1]

In general, there are two types of air distribution systems in hospital operation rooms that are commonly used: laminar diffuser systems and air curtain systems. Both systems have been widely used in all types of operating rooms because they have been proven effective at and beneficial for reducing the contamination with highly indoor air quality. For the current work, air laminar diffuser method is used. Joppolo et al., (2016) [2] showed that operating theatres [OTs] with unidirectional air flow diffusers system have mainly less inert and viable airborne particle concentration of pollutants within the operating theatre than those with bidirectional air flow, and therefore a less risk of surgical those with bidirectional air flow, and therefore a less risk of surgical site infections [SSIs]. Also, Cao et al., (2019) [3] examined the performance analysis of laminar air flow [LAF] and mixing ventilation [MV] in surgical operating rooms at St. Olavs Hospital in Norway. Their experimental investigations were conducted with two different systems: laminar air flow ventilations system and mixing ventilation systems. Under real surgical operating conditions, air flow distribution of the laminar airflow system was disrupted and air velocity was lower than that of the mixed ventilations above the surgical site. Airflow patterns were observed while distributed vertically downward and horizontally with laminar air diffusers and mixing ventilations, respectively. Vortex intensity of inlet airflow from laminar air flow was much lower than that of mixing ventilations.

The positions of air supply and exhaustion play a very important role in achieving the best performance in the distribution system of ventilation. Carla Balocco et al., (2015) [4] introduced a design and a location of air inlet diffusers on the compliance of microclimatic environment within the suggested code limits. They discovered that the air flow with the unidirectional systems is advantageous in reducing the heat stratification effect, which provides an adequate washing effect against airborne particles/contaminants and infection hazer at the surgical operating site. Thool and Sinha (2014) 
[5] investigated two types of ventilation distribution systems, which were analyzed by CFD simulation program in the view of pollution risk control. These two systems are conventional inlet at a high level and exhaust at a low level (Case 1), and inlet at a low level and outlets at a high level (Case 2). The results of the numerical simulation show that the ventilation system of Case 2 is safer than Case 1 in terms of the contaminated airborne particle strikes on the critical site of the surgical operating room. Sasan Sadrizadeh et al., (2014) [6] compared two different types of laminar airflow distribution systems: (1) horizontal and (2) vertical.

They discovered that, under corresponding conditions in the examined surgical operating room, the horizontal air laminar ventilation distribution system was preferred over the vertical one. Zoon et al., (2011) [7] argued that a higher ventilation position for the supply of air or recirculation mixing rate directly gives a lower airborne concentration of particles. Laminar air-diffuser are assumed to give pure air to critical sites before it mixes with contaminated air. From the receding literature review, this current work focuses on the first four factors: air distribution, air velocity, relative humidity and temperature.

In this work, two numerical sets of data will be compared: (1) Case I, numerical and experimental studies will be compared and (2) a suggested modification by the authors, Case II. The second case is not yet validated with any experimental data because it is a new suggestion. The main difference between Case I and Case II is the location of the exhaust outlet grill as will be discussed later.

(C) The Author(s) 2021. This article is licensed under a Creative Commons Attribution 4.0 International License, which permits use, sharing, adaptation, distribution and reproduction in any medium or format, as long as you give appropriate credit to the original author(s) and the source, provide a link to the Creative Commons licence, and indicate if changes were made. The images or other third party material in this article are included in the article's Creative Commons licence, unless indicated otherwise in a credit line to the material. If material is not included in the article's Creative Commons licence and your intended use is not permitted by statutory regulation or exceeds the permitted use, you will need to obtain permission directly from the copyright holder. To view a copy of this licence, visithttp://creativeco mmons.org/licenses/by/4.0/

\section{Room Geometry}

The operating room under investigation is a room in the Mataria teaching hospital. The room dimensions are shown in Figure 1, which illustrates the as-built drawings for ceiling and an elevation view of all the sides of the operation room. The supply laminar flow diffusers and exhaust air grills are shown in Figure 3, where there are (1) four vertical laminar air flow diffusers of a dimension of $60 \mathrm{~cm} \times 120 \mathrm{~cm}$ with HEPA filters, and (2) two exhaust grills at a low level with a dimension of $52 \mathrm{~cm} \times 103 \mathrm{~cm}$, and exhaust grills at a high level with a dimension of $23 \mathrm{~cm} \times 43 \mathrm{~cm}$. In this existing arrangement, it can be observed that all exhaust grills are in the same direction. In Case II, a similar arrangement of Case I is used with the changing of only the location of the exhaust grills as it shown in Figure 2, where the exhaust grills are located in opposite directions.

\section{Experimental Configurations Of The Operating Room}

As a first step in our experiment, we recorded some readings of temperature, velocity and humidity of several points of the existing arrangement Case I in Figure 1. In the following sections, the measuring procedures are discussed.

\subsection{Measuring Instrument}

In order to obtain complete analysis and investigation, temperature, velocity and humidity should be visualized and extracted. TENMARS-TM-411/412/413/414-air velocity meter is used for this investigation. This device measures air speed, temperature and humidity. It is ideal in spotting measurements at the air outlets on account of its $30 \mathrm{~mm}$ vane.

Page $3 / 23$ 


\subsection{Measuring Locations}

Measurements were performed at many different locations along the room, above the operation theatre and in front of the laminar flow diffuser. While point 1 is the midpoint of room volume, points 2, 3, 4 and 5 are at the front of the laminar air diffuser which the dimensions of the room $(x=4 \mathrm{~m}, y=2.65$ and $z=6 \mathrm{~m})$. The measurement points are distributed in the room volume as tabulated in Table 1.

Table 1

Locations of each measuring point in the room

\begin{tabular}{|llllllll|}
\hline Point & $X(m)$ & $Y(m)$ & $Z(m)$ & Point & $X(m)$ & $Y(m)$ & $Z(m)$ \\
\hline 1 & 0 & 0 & 0 & 17 & 0 & 1.25 & 3 \\
\hline 2 & 0.5 & 1.4 & 1 & 18 & 0 & 0 & 3 \\
\hline 4 & 0.5 & 1.4 & -1 & 19 & 0 & -1.25 & 3 \\
\hline 5 & -0.5 & 1.4 & 1 & 20 & -2 & 1.25 & 3 \\
\hline 6 & 2 & 1.25 & 0 & 22 & -2 & -1.25 & 3 \\
\hline 7 & 2 & 0 & 0 & 23 & 2 & 1.25 & -3 \\
\hline 8 & 2 & -1.25 & 0 & 24 & 2 & 0 & -3 \\
\hline 9 & 0 & 1.25 & 0 & 25 & 2 & -1.25 & -3 \\
\hline 10 & 0 & -1.25 & 0 & 26 & 0 & 1.25 & -3 \\
\hline 11 & -2 & 1.25 & 0 & 27 & 0 & 0 & -3 \\
\hline 12 & -2 & 0 & 0 & 28 & 0 & -1.25 & -3 \\
\hline 13 & -2 & -1.25 & 0 & 29 & -2 & 1.25 & -3 \\
\hline 14 & 2 & 1.25 & 3 & 30 & -2 & 0 & -3 \\
\hline 15 & 2 & 0 & 3 & 31 & -2 & -1.25 & -3 \\
\hline 16 & 2 & -1.25 & 3 & & & & \\
\hline
\end{tabular}

\subsection{Experimental Procedure}

The experimental investigation was done under prevailing and steady conditions, and thus we attained and verified them by recording and checking the room wall temperature by mounting a thermocouple on the walls of the operating room. The following steps were carried out to obtain each measurement:

1- Checking that the air conditioning system is working under steady state conditions;

2- The velocity and temperature measuring instrument are appropriately aligned and rigidly mounted on the supporting structure

3- The experimental apparatus is located at the exact point in the desired plane as in Figure 4 (Case I);

4- Calibration of the instrument is given in appendix (A); and 
5 - The supply air velocity was set to $0.45 \mathrm{~m} / \mathrm{s} \pm 0.05 \mathrm{~m} / \mathrm{s}$, also the supply air temperature was set to $17-25$ oC \pm 0.5 oC. The relative humidity of the supply air was set to $40-55 \% \pm 0.5$ at the inlet

\subsection{Experimental Results}

The recorded measurements of velocity, temperature and humidity in the existing room arrangement (Case I in Figure 1 are listed in Table 2. 
Table 2

Temperature, velocity and humidity measurement points and locations in the room

\begin{tabular}{|c|c|c|c|c|c|}
\hline Point & $\begin{array}{l}\text { Date } \\
\text { (dd/mm/yy) }\end{array}$ & $\begin{array}{l}\text { Time } \\
\text { (hh:mm:ss) }\end{array}$ & $\begin{array}{l}\text { Temperatue } \\
\left({ }^{\circ} \mathrm{C}\right)\end{array}$ & $\begin{array}{l}\text { Velocity } \\
(\mathrm{m} / \mathrm{s})\end{array}$ & $\begin{array}{l}\text { Humidity } \\
(\%)\end{array}$ \\
\hline 1 & 05/10/2019 & 10:00:00 & 20.12 & 0.28 & 44 \\
\hline 2 & 05/10/2019 & 10:03:05 & 17.60 & 0.4 & 47 \\
\hline 3 & 05/10/2019 & 10:06:15 & 17.70 & 0.4 & 47 \\
\hline 4 & 05/10/2019 & 10:09:04 & 17.70 & 0.42 & 47 \\
\hline 5 & 05/10/2019 & 10:12:09 & 17.70 & 0.41 & 47 \\
\hline 6 & 05/10/2019 & $10: 15: 02$ & 19.60 & 0 & 44 \\
\hline 7 & 05/10/2019 & 10:18:08 & 18.30 & 0.11 & 46 \\
\hline 8 & 05/10/2019 & 10:21:02 & 18.00 & 0.11 & 45 \\
\hline 9 & 05/10/2019 & $10: 24: 03$ & 18.50 & 0.21 & 45 \\
\hline 10 & 05/10/2019 & $10: 27: 00$ & 17.70 & 0.17 & 45 \\
\hline 11 & 05/10/2019 & 10:30:01 & 19.30 & 0 & 45 \\
\hline 12 & 05/10/2019 & 10:33:05 & 18.20 & 0 & 45 \\
\hline 13 & 05/10/2019 & $10: 36: 03$ & 17.60 & 0.11 & 46 \\
\hline 14 & 05/10/2019 & 10:39:07 & 18.30 & 0.2 & 44 \\
\hline 15 & 05/10/2019 & $10: 32: 12$ & 17.90 & 0.2 & 46 \\
\hline 16 & 05/10/2019 & $10: 35: 20$ & 17.90 & 0.1 & 46 \\
\hline 17 & 05/10/2019 & 10:38:11 & 18.90 & 0 & 44 \\
\hline 18 & 05/10/2019 & 10:41:01 & 18.00 & 0 & 46 \\
\hline 19 & 05/10/2019 & 10:43:02 & 17.70 & 0.1 & 46 \\
\hline 20 & 05/10/2019 & 10:47:06 & 18.60 & 0.2 & 44 \\
\hline 21 & 05/10/2019 & $10: 50: 03$ & 17.80 & 0.1 & 46 \\
\hline 22 & 05/10/2019 & 10:53:04 & 17.80 & 0.1 & 46 \\
\hline 23 & 05/10/2019 & 10:56:01 & 20.10 & 0 & 50 \\
\hline 24 & 05/10/2019 & 10:59:02 & 17.60 & 0.1 & 47 \\
\hline 25 & 05/10/2019 & 11:02:04 & 17.90 & 0.1 & 47 \\
\hline 26 & 05/10/2019 & 11:05:01 & 20.00 & 0 & 50 \\
\hline 27 & 05/10/2019 & 11:08:01 & 18.3 & 0.1 & 49 \\
\hline 28 & 05/10/2019 & 11:11:07 & 18.00 & 0.1 & 47 \\
\hline 29 & 05/10/2019 & 11:14:02 & 20.20 & 0 & 50 \\
\hline 30 & 05/10/2019 & 11:17:03 & 17.7 & 0.1 & 47 \\
\hline
\end{tabular}




\begin{tabular}{|llllll|}
\hline Point & $\begin{array}{l}\text { Date } \\
(\mathbf{d d} / \mathrm{mm} / \mathrm{yy})\end{array}$ & $\begin{array}{l}\text { Time } \\
(\mathrm{hh}: \mathrm{mm}: \mathbf{s s})\end{array}$ & $\begin{array}{l}\text { Temperatue } \\
\left({ }^{\circ} \mathrm{C}\right)\end{array}$ & $\begin{array}{l}\text { Velocity } \\
(\mathrm{m} / \mathrm{s})\end{array}$ & $\begin{array}{l}\text { Humidity } \\
(\%)\end{array}$ \\
\hline 31 & $05 / 10 / 2019$ & $11: 20: 12$ & 17.9 & 0.1 & 47 \\
\hline
\end{tabular}

\section{Numerical Settings}

As discussed above, there are two numerical cases discussed here: (1) Case l, it is a case with a specific existing ventilation arrangement inside an operation room in an Egyptian hospital (Mataria). In this case, the numerical simulation of Case I is compared with our experimental measurements inside the same room in the same conditions. This case is used mainly to validate the numerical tools. (2) Case II is a suggested ventilation arrangement (numerical only). After this, Case I and Case II are compared and discussed. The arrangements and testing of the locations of probes of Case I and Case II have been illustrated in Figure 4 and Figure 5, respectively. The

simulations have been performed using SolidWorks software (Version 2019). In this software, in addition to the numerical boundary conditions, several issues were taken into consideration, such as the operating table, light pendants, surgery staff and the patient. The room under investigation has an operating table at its center. This table is 2 meters long, 1meter-wide (including space for all auxiliaries) and 1-meter-high (as an average height). The surgical staff consists of 2 persons located at fixed positions around the table. The main light of the room (located in the ceiling) is a LED light of 1.2-meter long. Moreover, $\mathrm{k}-\Sigma$ model was employed as a turbulent model. The room dimensions are shown in Figure 1, which illustrates the as-built drawings of the ceiling and the elevation view for every side of the operation room. The supply laminar flow diffusers and exhaust air grills are shown in Figure 3, which shows the operating room air terminal, where (1) four vertical laminar air flow diffusers of the dimension of $60 \mathrm{~cm} \times 120 \mathrm{~cm}$ with HEPA filters, and (2) two low level exhaust grills $(52 \mathrm{~cm} \times 103 \mathrm{~cm})$ and two high level exhaust grills $(23 \mathrm{~cm} \times 43 \mathrm{~cm})$. In this existing arrangement, it can be observed that the exhaust grills are in the same direction. [In Case II, a similar arrangement of Case I is used with changing only the location of the exhaust grills as shown in Figure 2 . The supply air velocity was set to $0.45 \mathrm{~m} / \mathrm{s}$, the supply air temperature was set to $17 \mathrm{oC}$, and the relative humidity of the supply air was set to $40 \%$. Outdoor temperature was set to $30 \mathrm{oC}$.

\section{Result}

Tables 3 and 4 show the temperature, velocity and humidity values of the testing probes (see Figure 4 and Figure 5) for Case I and Case II, respectively. 
Table 3

Values of temperature, velocity and humidity measurement points (numerically) in the room (Case I)

\begin{tabular}{|c|c|c|c|c|c|c|}
\hline Point & $X[\mathrm{~m}]$ & $\mathrm{Y}[\mathrm{m}]$ & $\mathrm{Z}[\mathrm{m}]$ & Temperature (Fluid) $\left[{ }^{\circ} \mathrm{C}\right]$ & $\begin{array}{l}\text { Velocity } \\
{[\mathrm{m} / \mathrm{s}]}\end{array}$ & $\begin{array}{l}\text { Relative Humidity } \\
\text { [\%] }\end{array}$ \\
\hline 1 & 0 & 0 & 0 & 19.4 & 0.2903 & 44.14 \\
\hline 2 & 0.5 & 1.4 & 1 & 17.5 & 0.4299 & 47.57 \\
\hline 3 & 0.5 & 1.4 & -1 & 17.5 & 0.4261 & 47.57 \\
\hline 4 & -0.5 & 1.4 & 1 & 17.6 & 0.4572 & 47.57 \\
\hline 5 & -0.5 & 1.4 & -1 & 17.5 & 0.4251 & 47.57 \\
\hline 6 & 2 & 1.25 & 0 & 19.5 & 0.0452 & 43.22 \\
\hline 7 & 2 & 0 & 0 & 17.9 & 0.0552 & 46.77 \\
\hline 8 & 2.4 & -1.5 & 0 & 17.8 & 0.097 & 46.57 \\
\hline 9 & 0 & 1 & 0 & 18.4 & 0.0647 & 43.51 \\
\hline 10 & 0 & -1.25 & 0 & 17.6 & 0.2136 & 47.31 \\
\hline 11 & -2 & 1.25 & 0 & 18.9 & 0.0428 & 45.45 \\
\hline 12 & -2 & 0 & 0 & 17.9 & 0.0308 & 46.63 \\
\hline 13 & -2 & -1.25 & 0 & 17.8 & 0.2158 & 46.93 \\
\hline 14 & 2 & 1.25 & 3 & 19.7 & 0.173 & 46.01 \\
\hline 15 & 2 & 0 & 3 & 17.7 & 0.1355 & 46.68 \\
\hline 16 & 2 & -1.25 & 3 & 17.7 & 0.0978 & 47.11 \\
\hline 17 & 0 & 1.25 & 3 & 19.6 & 0.0121 & 43.74 \\
\hline 18 & 0 & 0 & 3 & 17.9 & 0.0497 & 46.87 \\
\hline 19 & 0 & -1.25 & 3 & 17.8 & 0.0766 & 46.98 \\
\hline 20 & -2 & 1.25 & 3 & 19.5 & 0.168 & 43.39 \\
\hline 21 & -2 & 0 & 3 & 17.7 & 0.041 & 47.09 \\
\hline 22 & -2 & -1.25 & 3 & 17.7 & 0.0802 & 47.08 \\
\hline 23 & 2 & 1.25 & -3 & 18.3 & 0.3783 & 42.72 \\
\hline 24 & 2 & 0 & -3 & 17.9 & 0.0721 & 46.738 \\
\hline 25 & 2 & -1.25 & -3 & 17.9 & 0.1158 & 46.85 \\
\hline 26 & 0 & 1.25 & -3 & 18.7 & 0.045 & 44.19 \\
\hline 27 & 0 & 0 & -3 & 18.0 & 0.0652 & 46.05 \\
\hline 28 & 0 & -1.25 & -3 & 17.9 & 0.2042 & 46.79 \\
\hline 29 & -2 & 1.25 & -3 & 18.4 & 0.5261 & 45.45 \\
\hline 30 & -2 & 0 & -3 & 17.9 & 0.0951 & 46.43 \\
\hline
\end{tabular}




\begin{tabular}{|lllllll|}
\hline Point & $\mathbf{X}[\mathrm{m}]$ & $\mathrm{Y}[\mathrm{m}]$ & $\mathrm{Z}[\mathrm{m}]$ & Temperature (Fluid) $\left[{ }^{\circ} \mathrm{C}\right]$ & $\begin{array}{l}\text { Velocity } \\
{[\mathrm{m} / \mathrm{s}]}\end{array}$ & $\begin{array}{l}\text { Relative Humidity } \\
{[\%]}\end{array}$ \\
\hline 31 & -2 & -1.25 & -3 & 17.8 & 0.1279 & 47.04 \\
\hline
\end{tabular}


Table 4

Values of temperature, velocity and humidity measurement points (numerically) in the room (Case II).

\begin{tabular}{|c|c|c|c|c|c|c|}
\hline Point & $X[\mathrm{~m}]$ & $\mathrm{Y}[\mathrm{m}]$ & $\mathrm{Z}[\mathrm{m}]$ & Temperature (Fluid) $\left[{ }^{\circ} \mathrm{C}\right]$ & $\begin{array}{l}\text { Velocity } \\
{[\mathrm{m} / \mathrm{s}]}\end{array}$ & $\begin{array}{l}\text { Relative Humidity } \\
\text { [\%] }\end{array}$ \\
\hline 1 & 0 & 0 & 0 & 18.7 & 0.2025 & 42.75 \\
\hline 2 & 0.5 & 1.4 & 1 & 17.5 & 0.4276 & 47.59 \\
\hline 3 & 0.5 & 1.4 & -1 & 17.5 & 0.4247 & 47.59 \\
\hline 4 & -0.5 & 1.4 & 1 & 17.5 & 0.3830 & 47.57 \\
\hline 5 & -0.5 & 1.4 & -1 & 17.5 & 0.4221 & 47.59 \\
\hline 6 & 2 & 1.25 & 0 & 19.1 & 0.0711 & 42.8 \\
\hline 7 & 2 & 0 & 0 & 17.8 & 0.1222 & 47.51 \\
\hline 8 & 2.4 & -1.5 & 0 & 17.9 & 0.1622 & 47.57 \\
\hline 9 & 0 & 1 & 0 & 19.0 & 0.0250 & 46.11 \\
\hline 10 & 0 & -1.25 & 0 & 17.6 & 0.0478 & 47.31 \\
\hline 11 & -2 & 1.25 & 0 & 18.3 & 0.0310 & 44.51 \\
\hline 12 & -2 & 0 & 0 & 17.8 & 0.1044 & 47.33 \\
\hline 13 & -2 & -1.25 & 0 & 17.7 & 0.2412 & 47.13 \\
\hline 14 & 2 & 1.25 & 3 & 18.1 & 0.4821 & 50.6 \\
\hline 15 & 2 & 0 & 3 & 17.9 & 0.0893 & 47.62 \\
\hline 16 & 2 & -1.25 & 3 & 17.7 & 0.1200 & 47.68 \\
\hline 17 & 0 & 1.25 & 3 & 18.9 & 0.0784 & 50.65 \\
\hline 18 & 0 & 0 & 3 & 17.8 & 0.0964 & 48.04 \\
\hline 19 & 0 & -1.25 & 3 & 17.8 & 0.0825 & 47.81 \\
\hline 20 & -2 & 1.25 & 3 & 19.3 & 0.0090 & 51.54 \\
\hline 21 & -2 & 0 & 3 & 17.7 & 0.0913 & 47.67 \\
\hline 22 & -2 & -1.25 & 3 & 17.7 & 0.1051 & 47.704 \\
\hline 23 & 2 & 1.25 & -3 & 19.3 & 0.0115 & 45.9 \\
\hline 24 & 2 & 0 & -3 & 17.8 & 0.0847 & 46.82 \\
\hline 25 & 2 & -1.25 & -3 & 17.8 & 0.1099 & 46.71 \\
\hline 26 & 0 & 1.25 & -3 & 18.7 & 0.0760 & 44.78 \\
\hline 27 & 0 & 0 & -3 & 18.1 & 0.0360 & 46.7 \\
\hline 28 & 0 & -1.25 & -3 & 17.8 & 0.2190 & 46.71 \\
\hline 29 & -2 & 1.25 & -3 & 18.3 & 0.5260 & 45.68 \\
\hline 30 & -2 & 0 & -3 & 17.9 & 0.0926 & 46.75 \\
\hline
\end{tabular}

Page $10 / 23$ 


\begin{tabular}{|lllllll|}
\hline Point & $X[\mathrm{~m}]$ & $\mathbf{Y}[\mathrm{m}]$ & $\mathbf{Z}[\mathrm{m}]$ & ${\text { Temperature (Fluid) }\left[{ }^{\circ} \mathrm{C}\right]}^{\text {Velocity }}$ & $\begin{array}{l}\text { Relative Humidity } \\
{[\mathrm{m} / \mathrm{s}]}\end{array}$ & {$[\%]$} \\
\hline 31 & -2 & -1.25 & -3 & 17.7 & 0.1316 & 46.93 \\
\hline
\end{tabular}

Figure 6, 7 and 8 show the cut planes of temperature, velocity, and humidity, respectively, for both cases: Case I (Left) and Case II (Right).

Figure 9,10 , and 11 show the temperature, velocity and relative humidity of three the cases at the testing probes (see Tables 1-4): (1) experimental data, (2) Case I, and (3) Case II. The current simulations (Case I, and Case II) show good agreement with the experimental data in terms of trends; discrepancies were of the order of less than one degree centigrade. It has been found that higher temperature at the probes 1, 21, 23, 26 and 29 reach 20。C, whereas the mean temperature along the room is $18 \circ \mathrm{C}$. The values of temperatures in Case I are always higher than that of Case II at most of the points. Same trend can be observed for velocity and relative humidity.

Air velocity meter that was used in the experimental investigations could not measure small digits, so the data at the points that have velocity less than $0.01 \mathrm{~m} / \mathrm{s}$ do not appear, such as points 6, 1, 12, 17, 18, 23, 26 and 29.

\section{Discussion}

From these temperatures, velocity and humidity measurements and the comparisons with the corresponding computations of the present work, one may adequately use the present computational model (SOLIDWORK simulation) to predict flow regimes and heat transfer in the operating rooms.

Operating Room (OR) Ventilation Systems Best Practices Guide for Energy Efficiency, Health and Safety [8] recommended the acceptable band within which the space conditions for every individual OR must be maintained. In particular, the upper limit of $60 \% \mathrm{RH}$ must not exceed this percentage so that the safety of materials and products within the OR may not be compromised. The airflow shall be unidirectional, downwards, and the average velocity, humidity and temperature in ANSI/ASHRAE/ASHE Standard [9] are as in Table 5. CAN/CSA Z317.2 standards [10] has special requirements for heating, ventilation and air conditioning (HVAC) systems in health care facilities (medical/surgical facilities). The recommendation for temperature in the operating room is in the range of $18-230 \mathrm{C}$ and humidity is in the range of $40-$ $60 \%$ according to the AIA (The American Institute of Architects Guidelines for Design Construction of HealthCare Facilities) [11]. 
Table 5

Design parameters in hospital spaces Ref. [9].

\begin{tabular}{|c|c|c|c|c|c|c|c|}
\hline Function of Space & $\begin{array}{l}\text { Pressure } \\
\text { Relationship } \\
\text { to Adjacent } \\
\text { Areas }\end{array}$ & $\begin{array}{l}\text { Minimum } \\
\text { Outdoor } \\
\text { ach }\end{array}$ & $\begin{array}{l}\text { Minimum } \\
\text { Total ach }\end{array}$ & $\begin{array}{l}\text { All Room } \\
\text { Air } \\
\text { Exhausted } \\
\text { Directly } \\
\text { to } \\
\text { Outdoors }\end{array}$ & $\begin{array}{l}\text { Air } \\
\text { Recirculate } \\
\text { by Means } \\
\text { of } \\
\text { Room } \\
\text { Units }\end{array}$ & $\begin{array}{l}\text { Design } \\
\text { Relative } \\
\text { Humidity } \\
\%\end{array}$ & $\begin{array}{l}\text { Design } \\
\text { Temperature } \\
{ }^{\circ} \mathrm{F} /{ }^{\circ} \mathrm{C}\end{array}$ \\
\hline \multicolumn{8}{|c|}{ SURGERY AND CRITICAL CARE } \\
\hline $\begin{array}{l}\text { Operating room } \\
\text { (m), }\end{array}$ & Positive & 4 & 20 & NR & NO & $20-60$ & $\begin{array}{l}68-75 / 20- \\
24\end{array}$ \\
\hline $\begin{array}{l}\text { Operating/surgical } \\
\text { cryptoscopic } \\
\text { rooms }\end{array}$ & Positive & 4 & 20 & NR & NO & $20-60$ & $\begin{array}{l}68-75 / 20- \\
24\end{array}$ \\
\hline
\end{tabular}

Table 5 Ventilation temperature and humidity requirements for areas affecting patients' care in hospitals and outpatient facilities 1 Ref. [9]

According to all codes and standards, it is clear that the values of velocity, temperature and relative humidity of Case I and II do fit with the codes and standards. But the velocities in Case II fit better than those of Case I. For example, in Figure 10 some velocity values are almost neglected in Case I such as the value of points 6, 1, 12, 17, 18, 23,26 and 29.

\subsection{Discussion of Case I}

In Case I, the most important average values are,

Average temperature: $18.19^{\circ} \mathrm{C}$;

Average velocity: $0.127 \mathrm{~m} / \mathrm{s}$;

Average relative humidity: $46.77 \%$.

The numerical investigation of the case I showed that there is non-homogeneous air distribution (poor ventilation) as it is clear from Figure 12, where there are two zones of distribution: Zone 1 is the area which has air outlet grills in its side. This Zone has more homogeneous air distribution compared to that of Zone 2. In fact, Zone 2 will lead to the accumulation of airborne particles (pollutants) and this may affect the quality and purity of the air inside the room. Also, on the left side of Figure 12, there are no outlet grills, a dead zone (Zone 3) has been created; this dead zone is a suitable environment for growing up of bacteria and viruses.

\subsection{Discussion of Case II}

In Case II, the most important average values are:

Average Temperature: $18.08^{\circ} \mathrm{C}$

Average Velocity: $0.133 \mathrm{~m} / \mathrm{s}$.

Average Relative Humidity: $46.0 \%$.

In this case, the flow pattern shows more homogenous air distribution as it can be observed in Figure 13. This homogenous distribution will lead to better ventilation compared to Case I, which means a healthier environment. 


\section{Conclusion}

The results showed that the introduced modification of the outlet arrangement in Case II has a better air distribution (ventilation) than the existing case (Case I). Therefore, it is recommended to put air outlets in two opposite sides inside the room in order to avoid the accumulation of contaminants. Additionally, the results also suggest that the supply air in the operating room by four laminar air flow diffusers in the middle of the ceiling above the surgical table is a convenient way to protect the surgical area from airborne particles. It has been found that adding the exhaust openings at opposite corners leads to a cleaner environment. Also, the lower grill has a larger size, while the lower grill reaches four times larger than the upper grill.

\section{References}

1. International Organization for Standardization. ISO 14644-1:2015, Cleanrooms and associated controlled environments (part 1); 2015.

2. Cesare M. Joppolo, et al., On field ventilation performance in operating theaters against airborne contamination a comparison of unidirectional and mixed airflow systems indoor air, 14th International Conference on Indoor Air Quality and Climate, At Ghent, Belgium (2016).

3. Guangyu Cao et al., Laminar airflow and mixing ventilation: Which is better for operating room airflow distribution near an orthopedic surgical patient, American Journal of Infection, (2019).

4. Carla Balocco, et al., Numerical investigation of different airflow schemes in a real operating theatre, Journal of Biomedical Science and Engineering, 8:02 (2015) 73-89.

5. Sanjeev B Thool and Shobha Lata Sinha, Numerical simulation and comparison of two conventional ventilation systems of operating room in the view of contamination control, International Journal of Computer Applications 85:5 (2014) 31-35.

6. Sadrizadeh S., et al., Numerical investigation of vertical and horizontal laminar airflow ventilation in an operating room, Building and Environment. 82 (2014) 517-525.

7. W.A.C. Zoon, M.G.L.C. Loomans, J.L.M. Hensen, Testing the effectiveness of operating room ventilation with regard to removal of airborne bacteria, Building and Environment, 46:12 (2011) 2570-2577.

8. Ian Jarvis, Operating Room Ventilation Systems Best Practices Guide for Energy Efficiency, Health and Safety, Greening Health Care, 2017, page 7, www.enerlife.com

9. R. American Society for Heating, air-conditioning Engineers Inc. ASHRAE/ASHE Standard 170: Ventilation of Health Care Facilities, 2017, Atlanta, USA,www.ashrae.org.

10. R. Canadian Standards Association (CSA), Special requirements for heating, ventilation and air-conditioning systems, health care facilities, CSA Z 317.2, 2019,

11. The American Institute of Architects. AIA, Guidelines for Design and Construction of Health Care Facilities, p 130133, 2006 https://www.aia.org/topics/31-design-and-health

\section{Appendix}

Appendix $A$ is not available with this version.

\section{Figures}




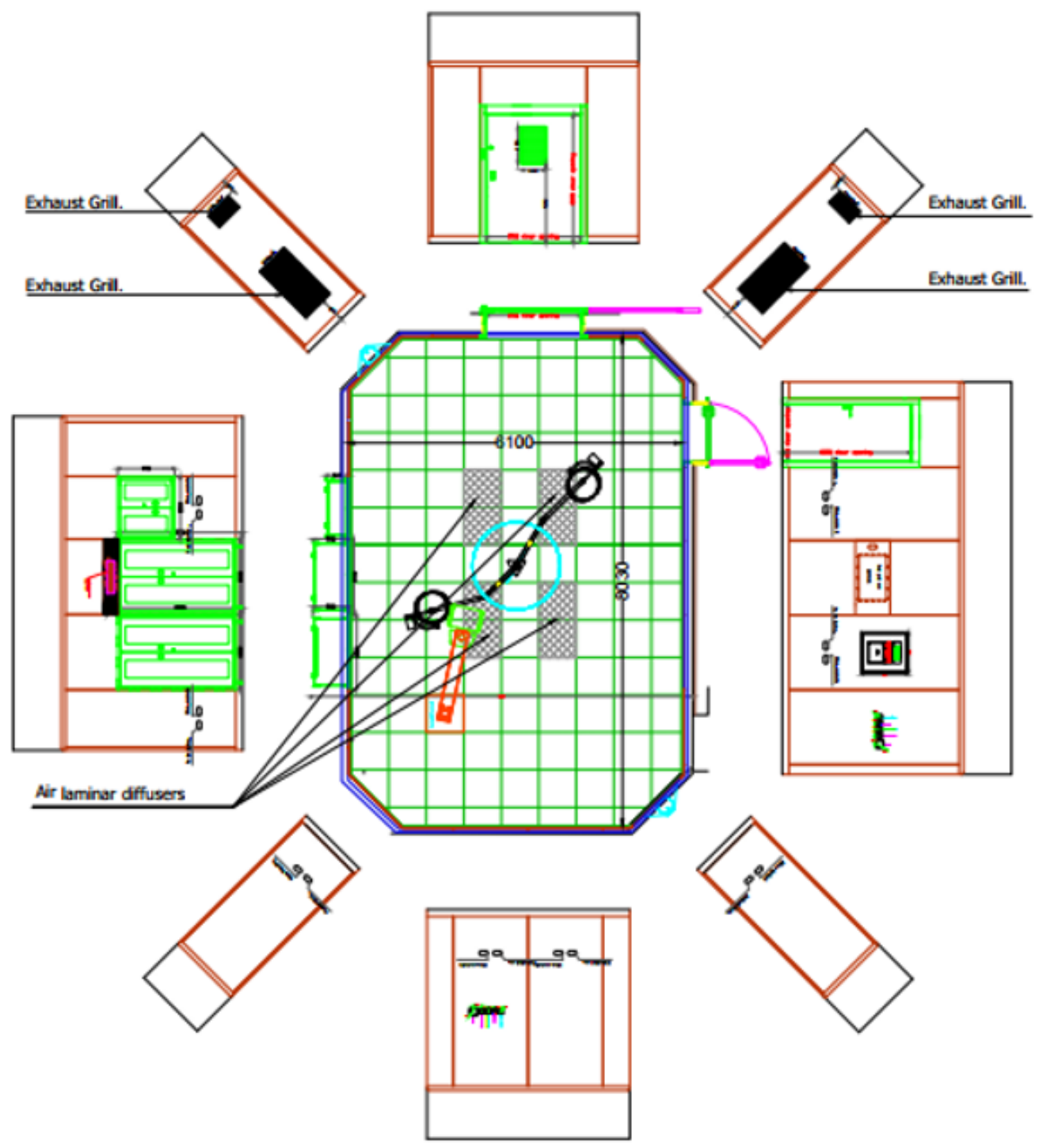

Figure 1

Operating room configuration showing the supply and exhaust air locations for Case I (all given dimensions are in $\mathrm{mm}$ ) 


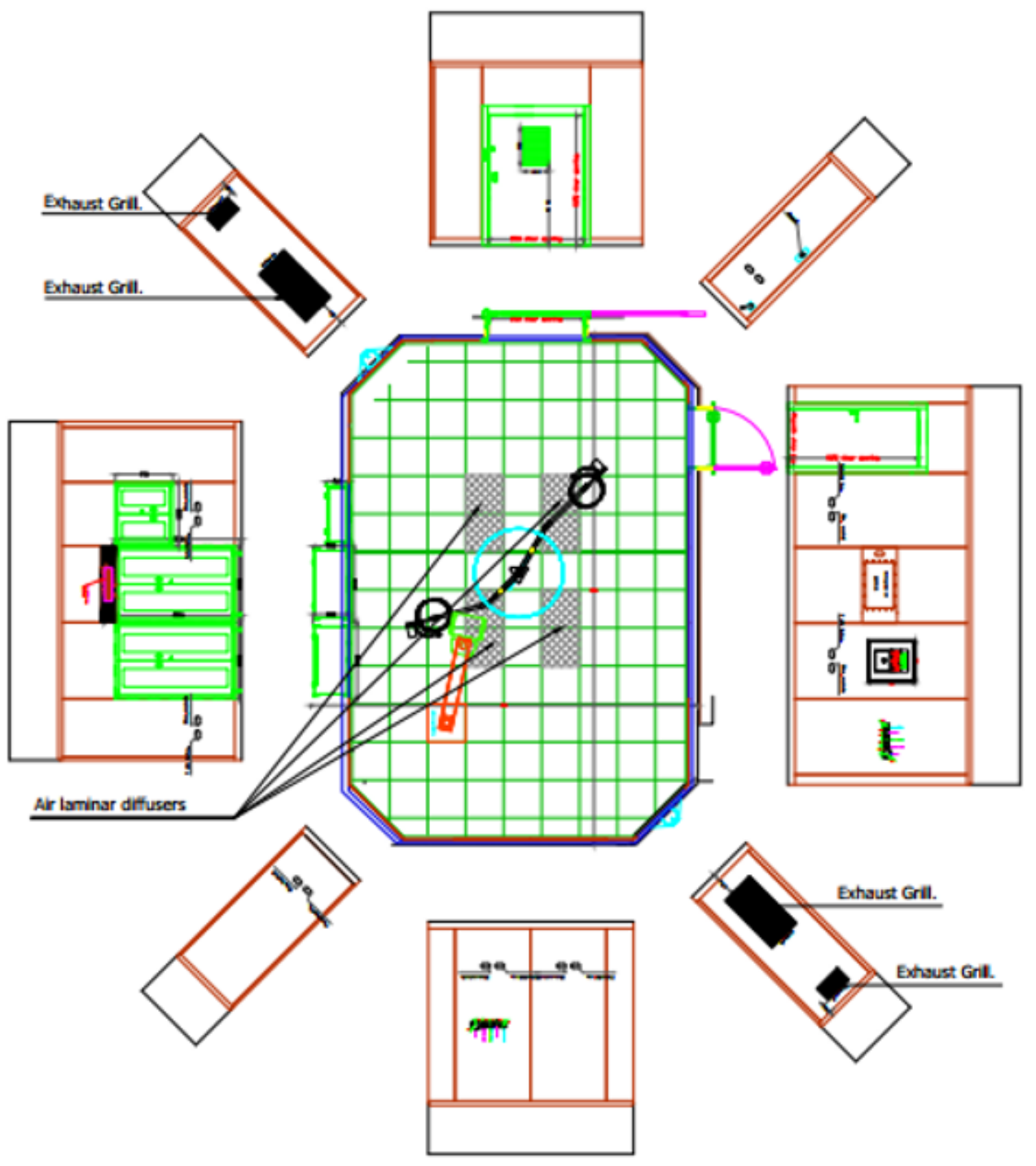

Figure 2

Operating room configuration showing the supply and exhaust air locations for Case II (all given dimensions are in $\mathrm{mm}$ ) 

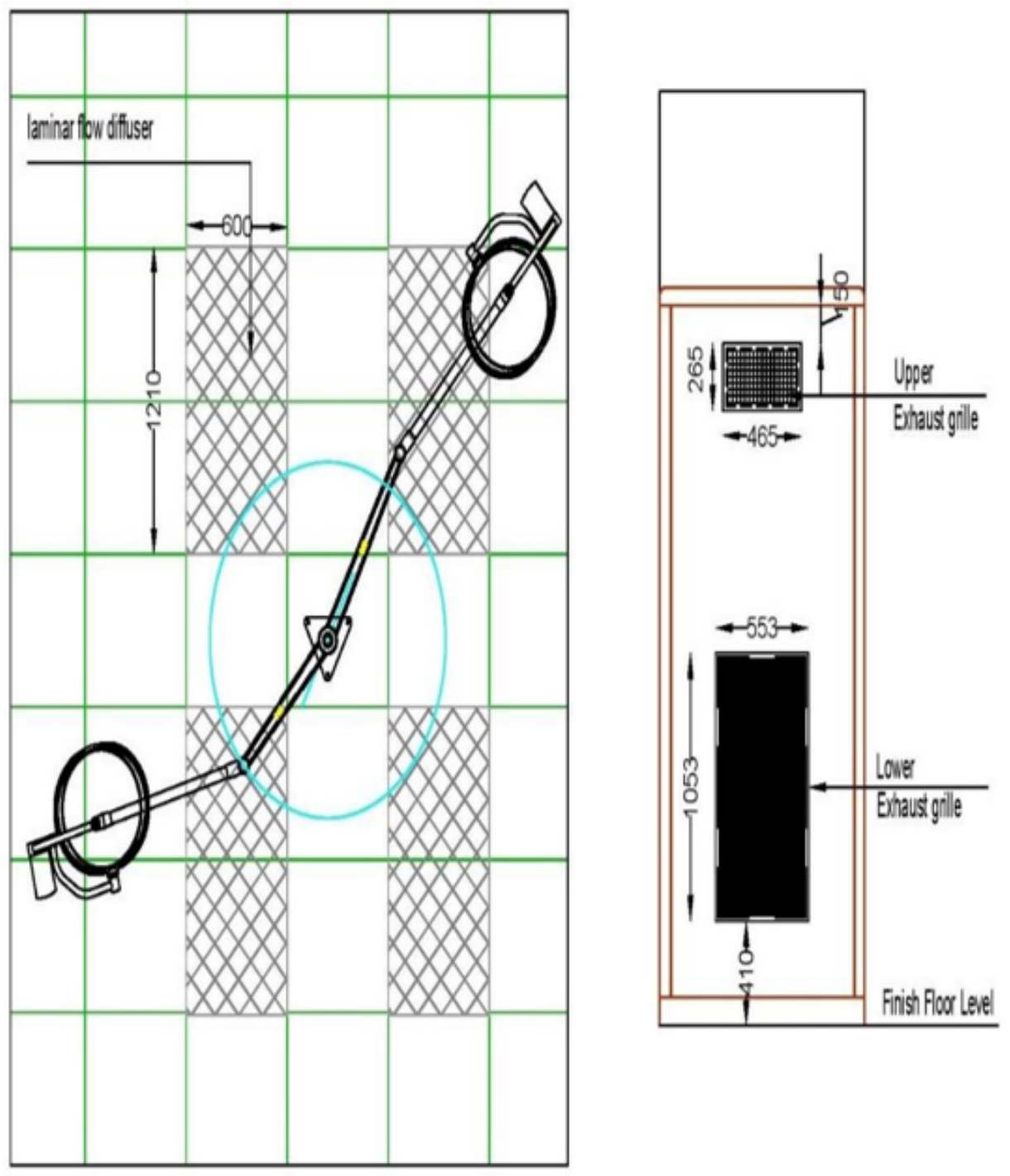

Figure 3

Supply and exhaust air configuration (all given dimensions are in $\mathrm{mm}$ ) 


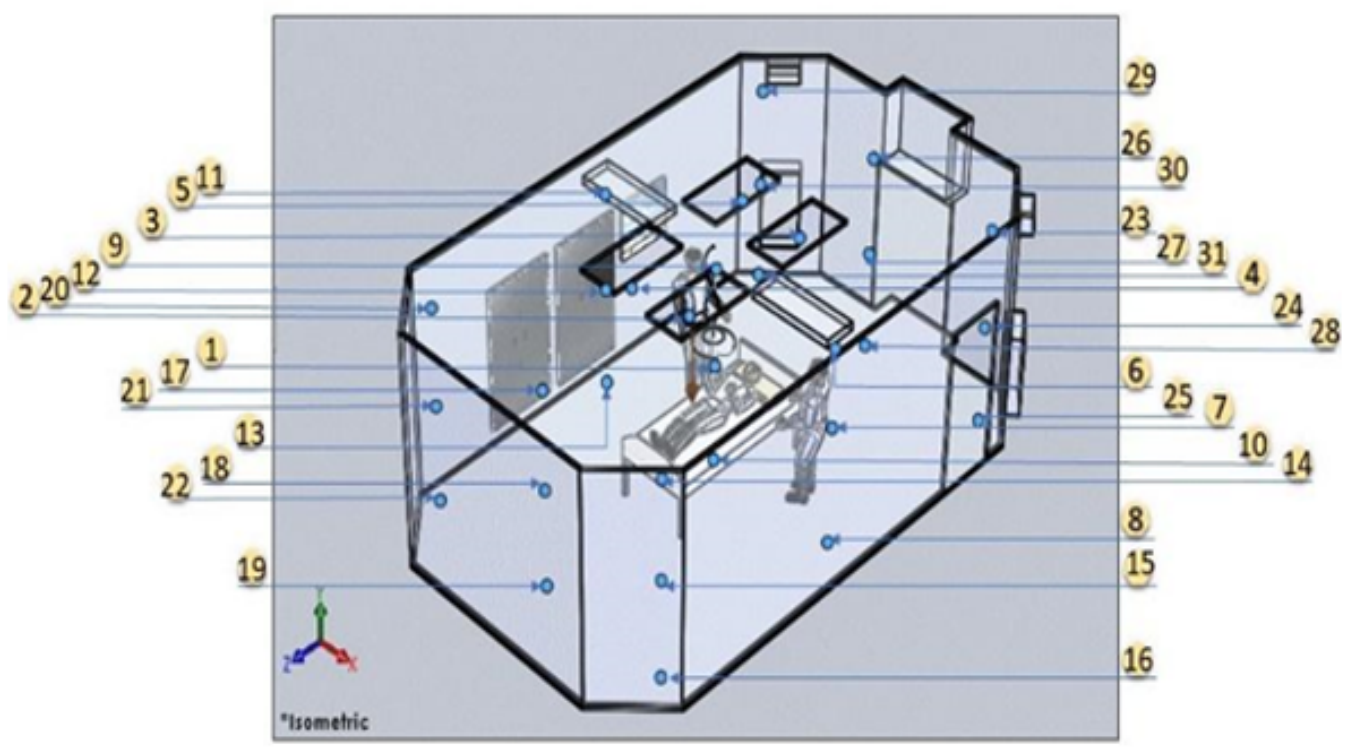

Figure 4

Numerical measurement point's location. Case I.

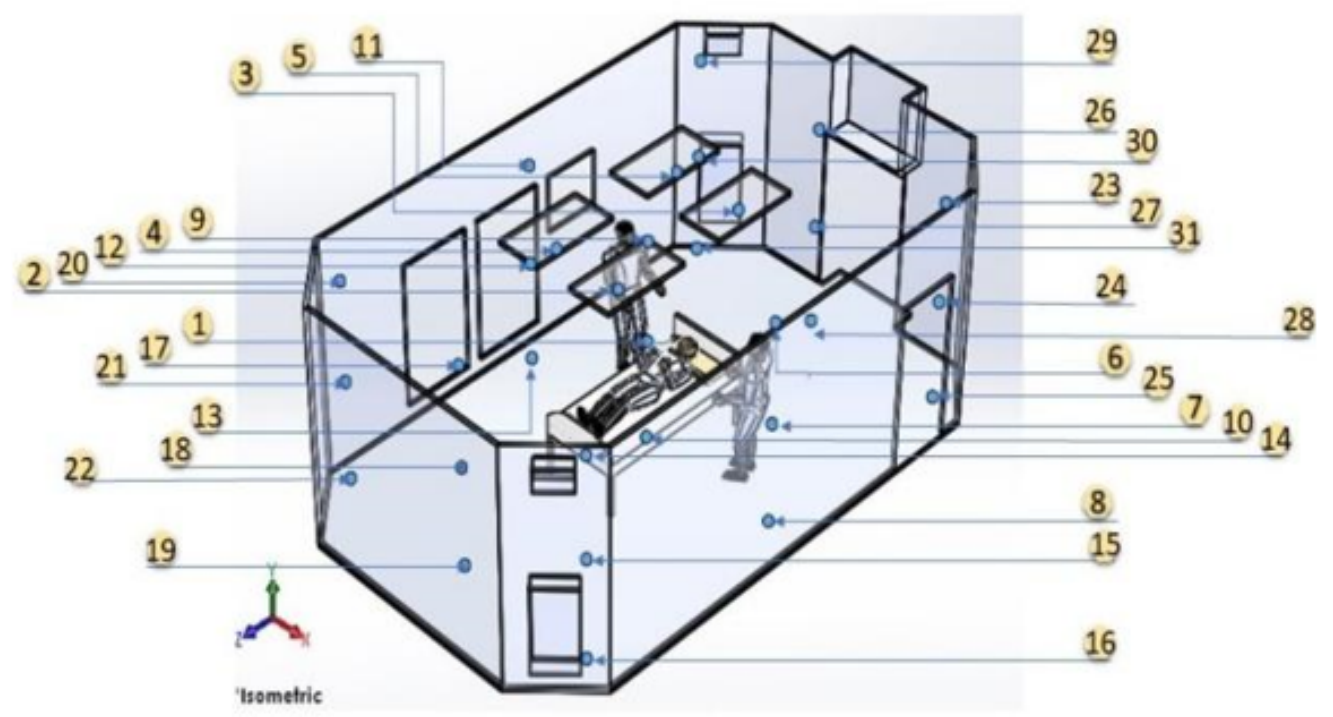

Figure 5

Numerical measurement point's location. Case II. 


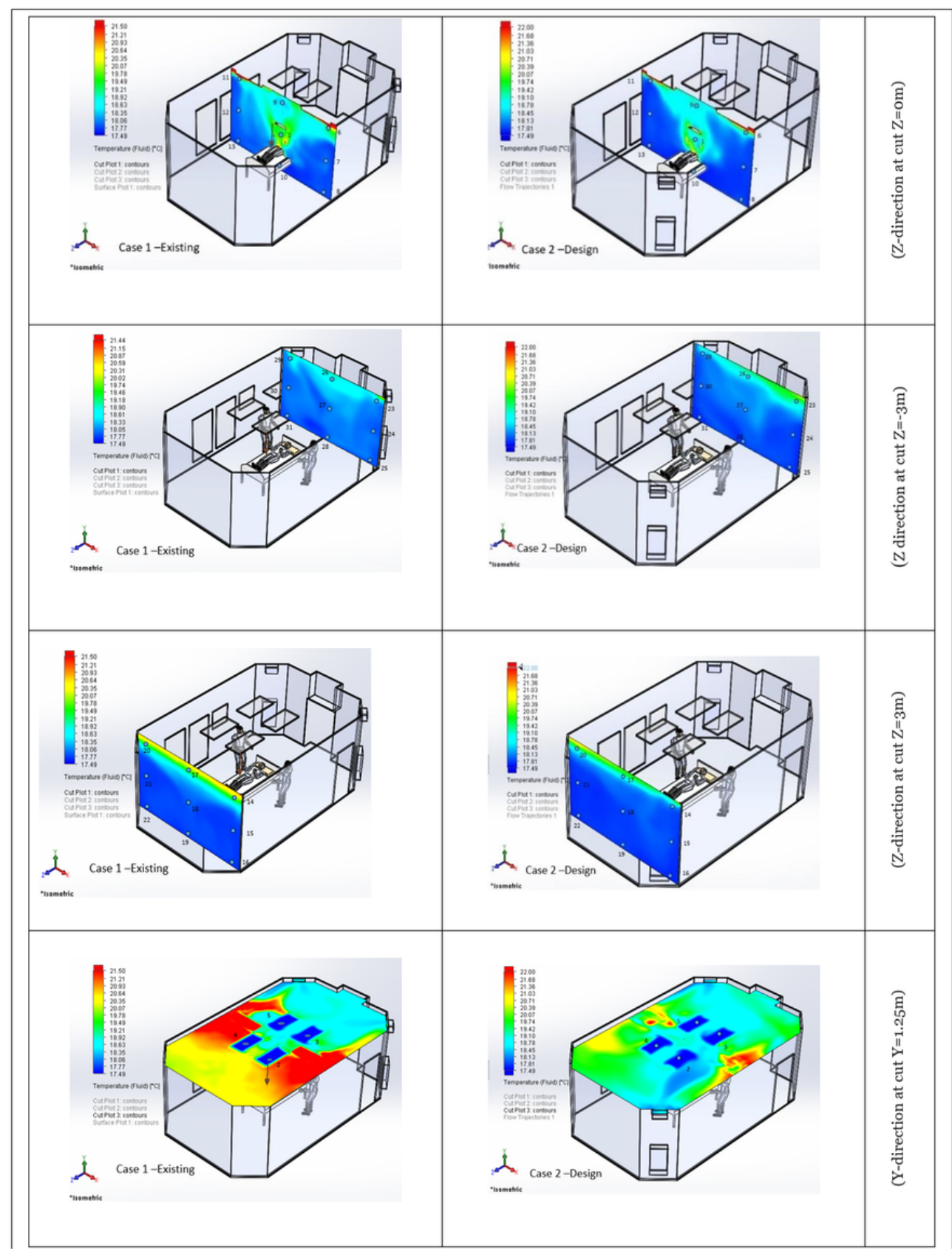

Figure 6

Cut planes showing the temperature distribution. Left: Case I. Right: Case II 


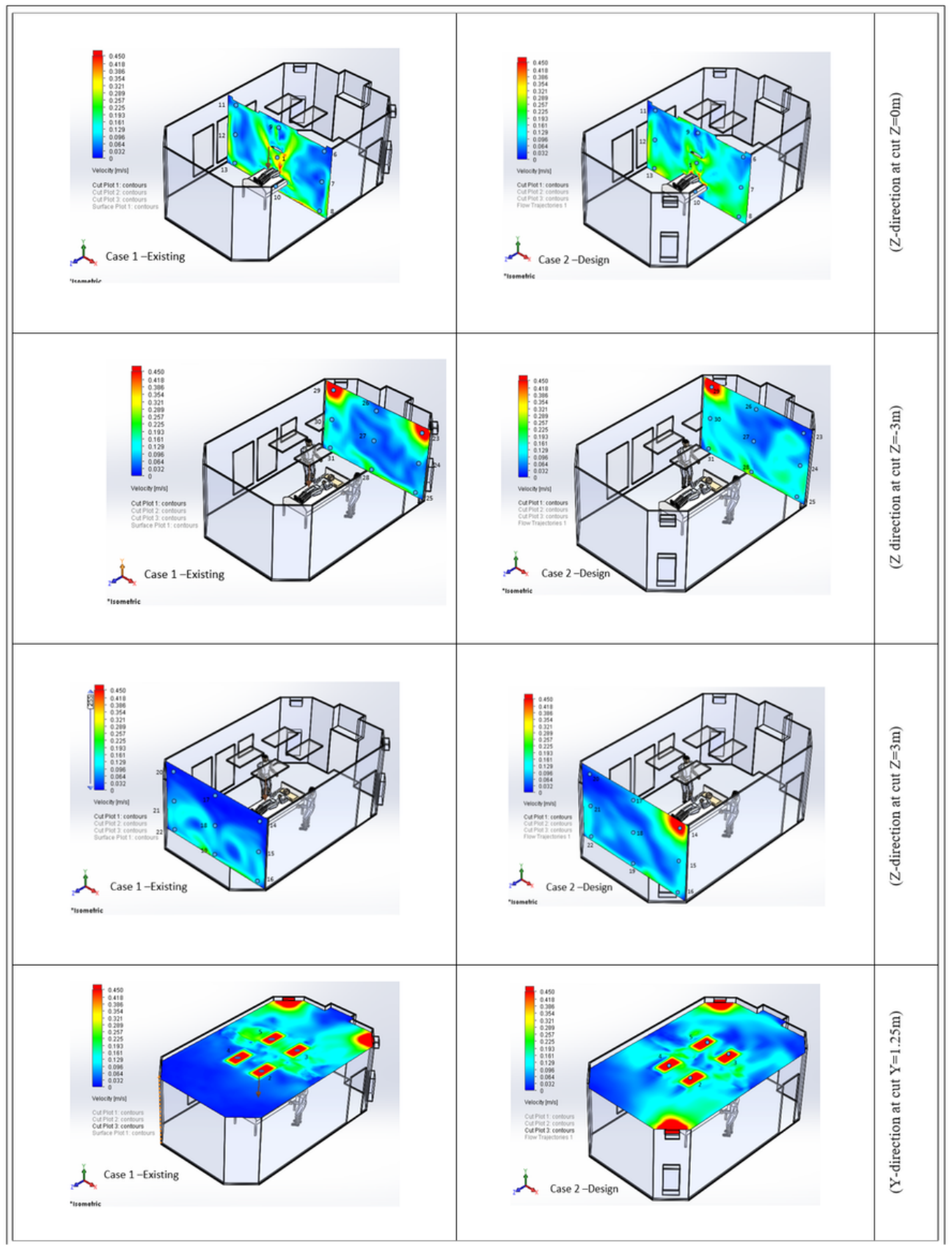

Figure 7

Cut planes showing the velocity distribution. Left: Case I. Right: Case II. 


(c) case 2-Desing 1-xising

Figure 8

Cut planes showing the humidity distribution. Left: Case I. Right: Case II 


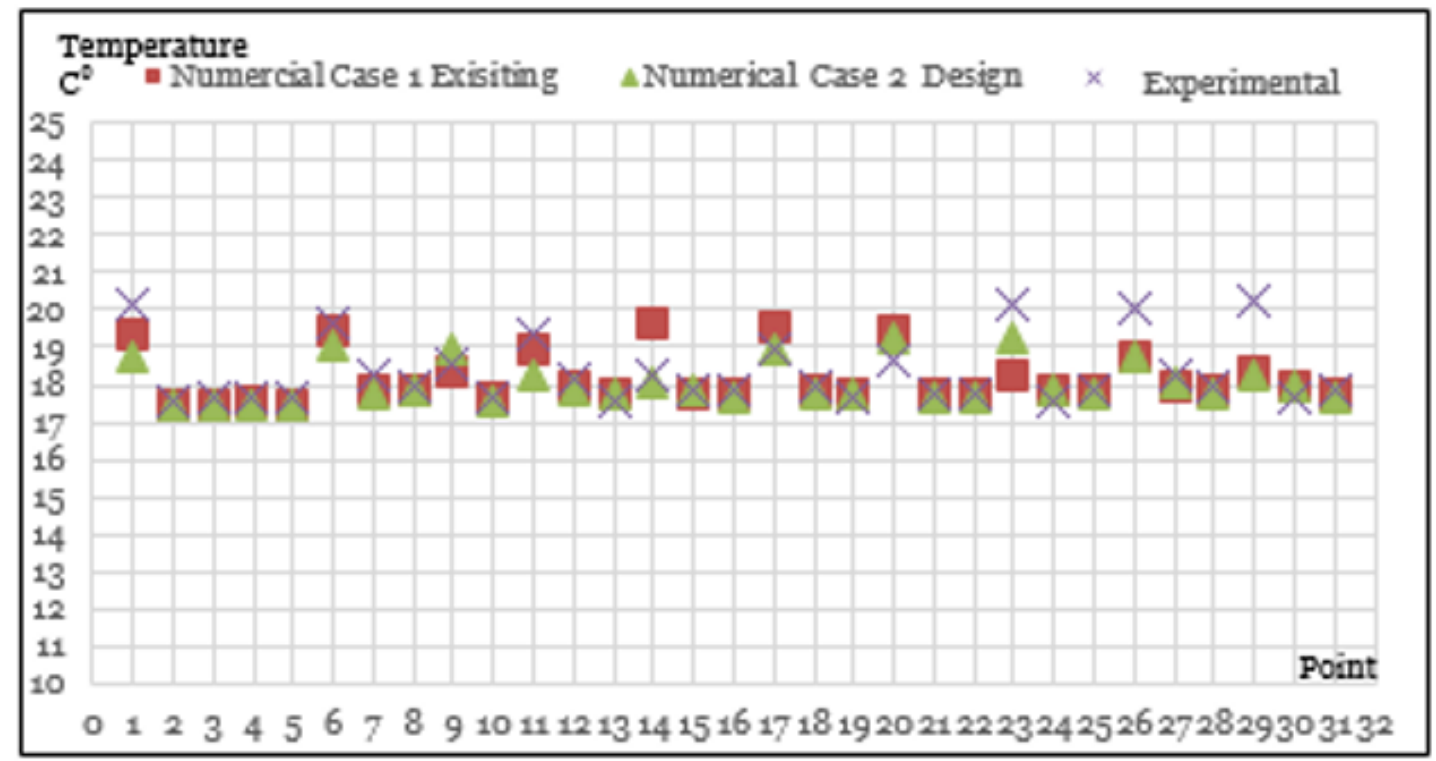

Figure 9

Temperature at each testing probes for Case I and Case II compared to the experimental measured data.

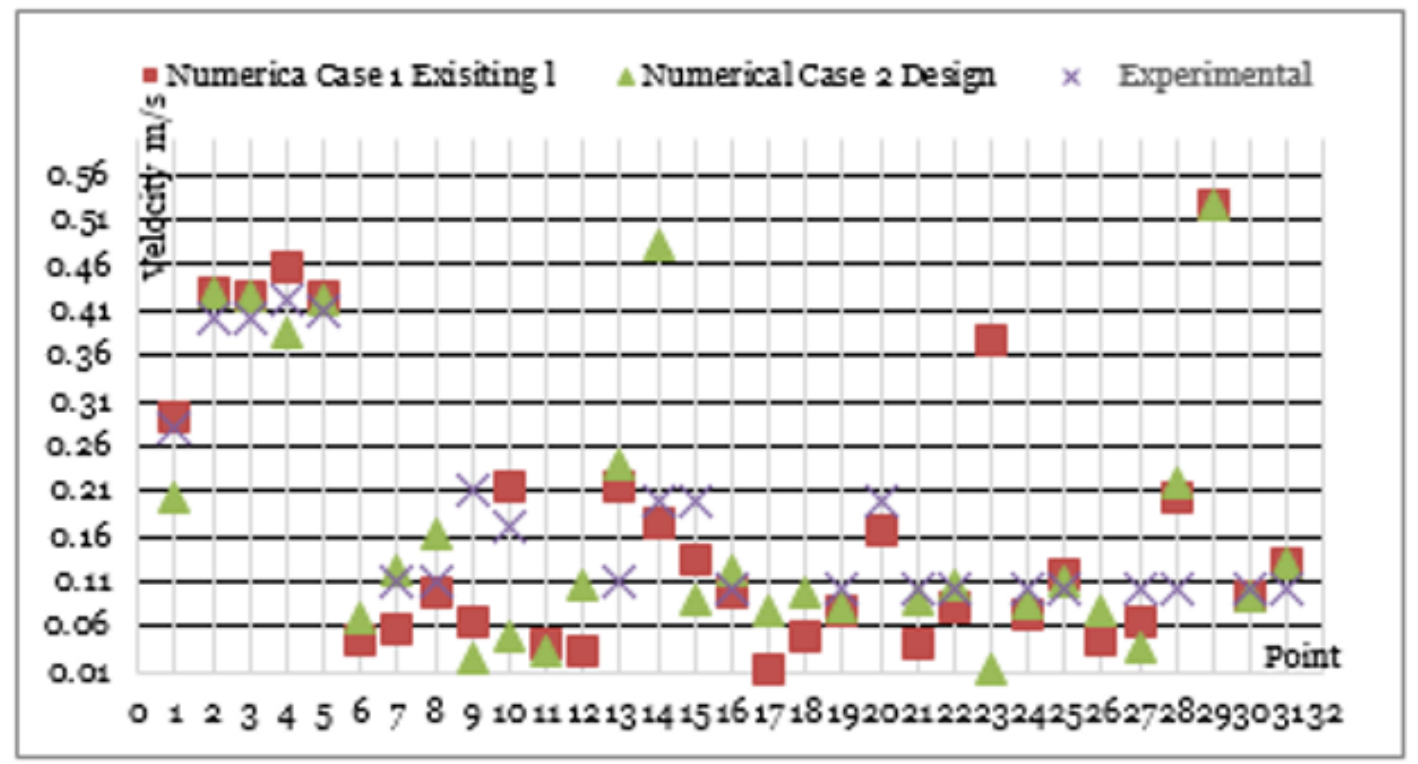

Figure 10

Velocity magnitude at each testing probes for Case I and Case II compared to the experimental measured data. 


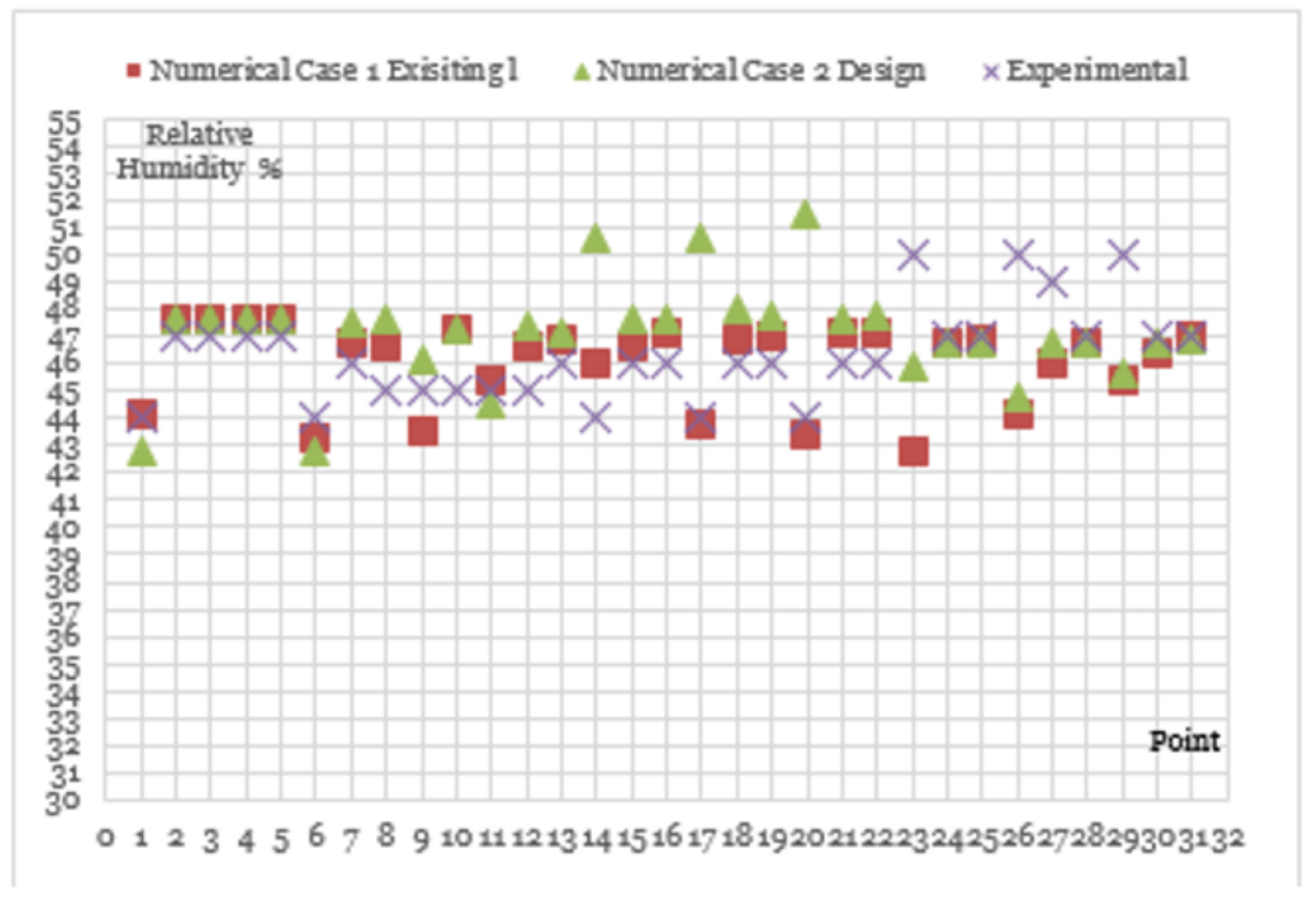

\section{Figure 11}

Relative humidity at each testing probes for Case I and Case II compared to the experimental measured data.

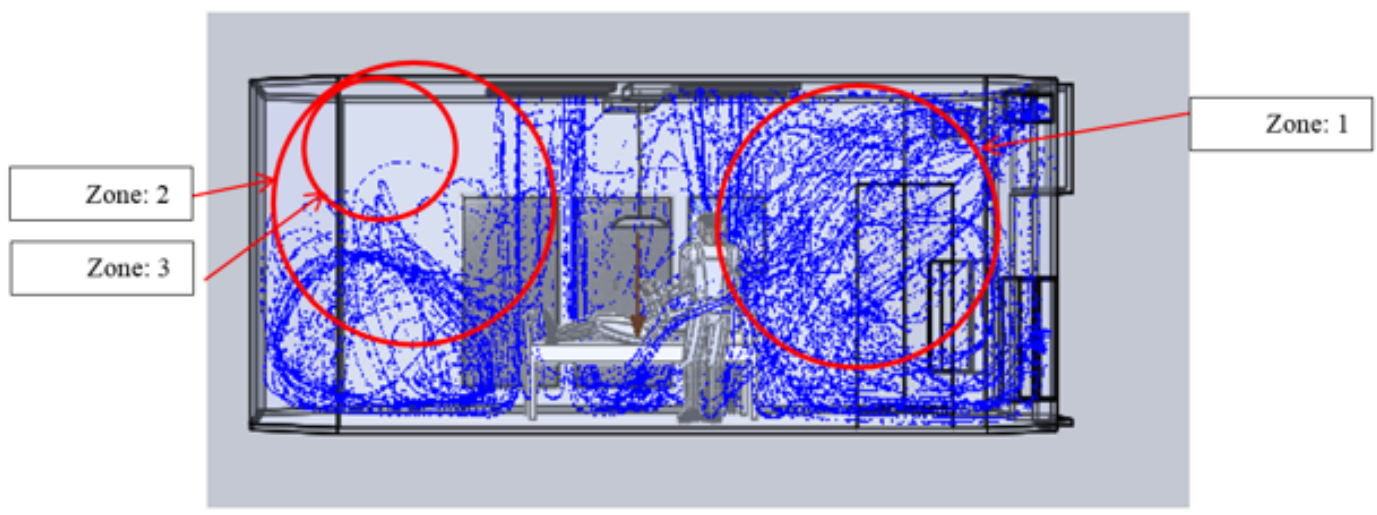

Figure 12

Side view of the flow pattern of the room for Case I. 


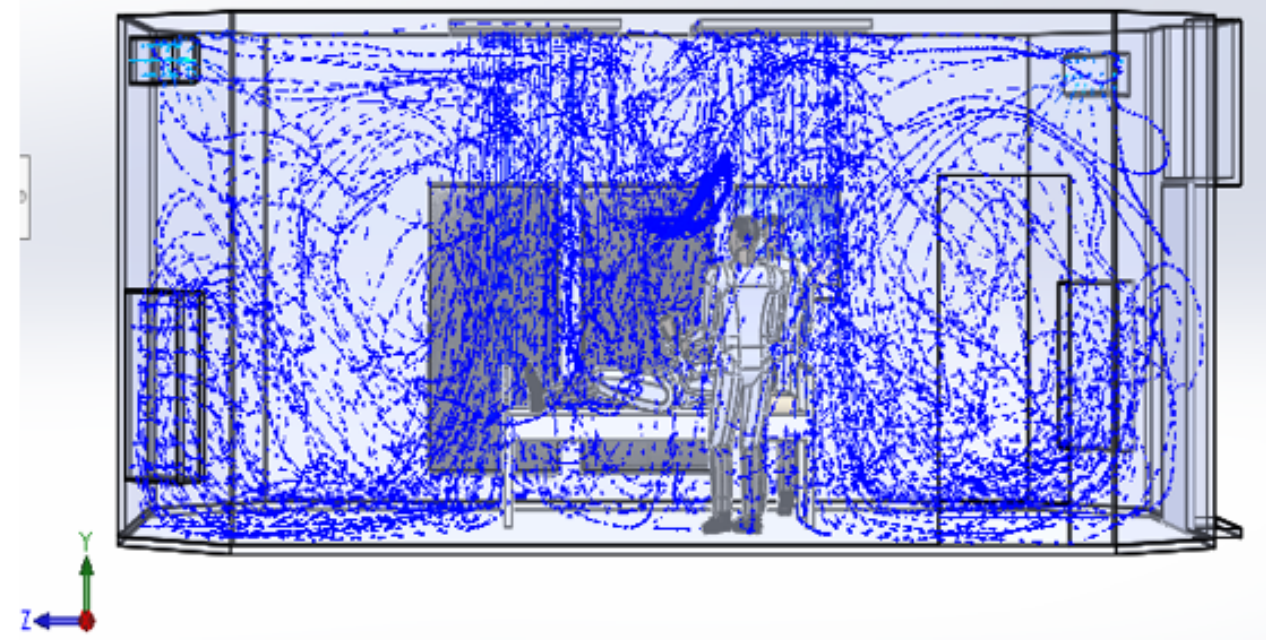

Figure 13

Side view of flow pattern at room for Case II. 